\title{
Hygiene quality of traditional and industrial table olives from markets in Rabat-Salé and Temara cities in Morocco
}

\author{
${ }^{* 1}$ Mennane, Z., ${ }^{2}$ Houlali, I., ${ }^{3}$ Charof, R., ${ }^{1}$ Abrini, J., and ${ }^{1}$ Elmtili, N. \\ ${ }^{1}$ Food and Health Team, Laboratory of Biology and Health, Faculty of Science, Abdelmalek Essaidi University, \\ P. O. Box 2121, Tetouan, Morocco \\ ${ }^{2}$ Faculty of Science and Technology, Beni Mellal, Environment Laboratory, Morocco \\ ${ }^{3}$ Laboratory of Medical Bacteriology, National Institute of Hygiene, Rabat, Morocco \\ Correspondence to: menzakaria@hotmail.com; 212634564754
}

\begin{abstract}
:
Background: Table olives are one of the most important vegetable canning products in Morocco, which is considered one of the world's largest producing countries. Currently, many outlets prepare table olives by different methods that do not comply with standard hygiene practices. Hence, this research was conducted to assess the quality standard of these olives by evaluating their physico-chemical and microbiological properties.

Methodology: A total of 108 samples of table olives (pitted green olives and blacks) obtained from Rabat-Salé and Rabat-Temara markets in Morocco were evaluated. Physico-chemical properties of the olives including $\mathrm{pH}$, oxido-reduction potential (ORP) and titrable acidity were determined using the analytical methods of the Association of Official Analytical Chemists (AOAC). Microbiological analyses including standard plate count (SPC) for total aerobic mesophilic flora (TAMB), total coliforms (TC), faecal coliforms (FC), yeasts, clostridia, Staphylococcus aureus, faecal streptococci and salmonella counts, were performed using standard microbiological methods. The identification of yeast isolates was carried out with the commercial API 20C biochemical identification kit.

Results: The average microbial loads for traditional olive samples were $3.2 \times 10^{6} \mathrm{CFU} / \mathrm{ml}$ for SPC, $1.7 \times 10^{4} \mathrm{CFU} / \mathrm{ml}$ for $\mathrm{TC}, 8.7 \times 10^{3} \mathrm{CFU} / \mathrm{ml}$ for $\mathrm{FC}$, and $2.5 \times 10^{6} \mathrm{CFU} / \mathrm{ml}$ for yeast, which were higher compared to the average microbial loads of industrial olives with values of $5.9 \times 10^{5} \mathrm{CFU} / \mathrm{ml}, 5 \times 10^{1} \mathrm{CFU} / \mathrm{ml}, 0 \mathrm{CFU} / \mathrm{ml}$ and $0 \mathrm{CFU} / \mathrm{ml}$ respectively. One hundred percent (56 of 56) of the traditional olives (pitted green and black) from Temara-Rabat markets were contaminated with coliforms while $50 \%$ of green and $65 \%$ of black olives in Salé-Rabat were contaminated with coliforms. Five percent $(5 \%)$ each of the traditional green and black olives in Salé-Rabat markets were contaminated with clostridia (spore forming bacteria). No FC or other bacteria and yeasts were present in the industrial olives, and none of the olives was contaminated with $S$. aureus, faecal streptococci and salmonella. Of the total of 8 yeast strains isolated from the traditional olives, 4 (50\%) were Candida guilliermondii, $2(25 \%)$ Candida lusitaniae and 2 (25\%) Candida famata.

Conclusion: The contamination of olive oil products may be due to different sources such as water, processing materials, storage condition, cleaning, labour and others. There is need for increase awareness and control of these at the points of sale of these traditional olives.
\end{abstract}

Keywords: hygiene; physico-chemical properties; microbiology; traditional olives; quality

Received May 18, 2020; Revised July 11, 2020; Accepted July 25, 2020

Copyright 2021 AJCEM Open Access. This article is licensed and distributed under the terms of the Creative Commons Attrition 4.0 International License $<$ a rel="license" href="http://creativecommons.org/licenses/by/4.0/", which permits unrestricted use, distribution and reproduction in any medium, provided credit is given to the original author(s) and the source. Editor-in-Chief: Prof. S. S. Taiwo

\section{Qualité Hygiène des olives de table traditionnelles et industrielles des marchés des villes de Rabat-Salé et Témara au Maroc}

\author{
${ }^{* 1}$ Mennane, Z., ${ }^{2}$ Houlali, I., ${ }^{3}$ Charof, R., ${ }^{1}$ Abrini, J., et ${ }^{1}$ Elmtili, N. \\ ${ }^{1}$ Équipe Alimentation et Santé, Laboratoire de Biologie et Santé, Faculté des Sciences, Université Abdelmalek \\ Essaidi, P. O. Box 2121, Tétouan, Maroc \\ ${ }^{2}$ Faculté des Sciences et Technologies, Beni Mellal, Laboratoire de l'Environnement, Maroc \\ ${ }^{3}$ Laboratoire de bactériologie médicale, Institut national d'hygiène, Rabat, Maroc \\ *Correspondance à: menzakaria@hotmail.com; 212634564754
}

\section{Resume:}

Contexte: Les olives de table sont l'un des produits de mise en conserve de légumes les plus importants au Maroc, qui est considéré comme l'un des plus grands pays producteurs du monde. Actuellement, de nombreux 
points de vente préparent les olives de table par différentes méthodes non conformes aux pratiques d'hygiène standard. Ainsi, cette recherche a été menée pour évaluer le standard de qualité de ces olives en évaluant leurs propriétés physico-chimiques et microbiologiques.

Méthodologie: Un total de 108 échantillons d'olives de table (olives vertes dénoyautées et noires) obtenus sur les marchés de Rabat-Salé et Rabat-Témara au Maroc ont été évalués. Les propriétés physico-chimiques des olives, y compris le $\mathrm{pH}$, le potentiel d'oxydoréduction (ORP) et l'acidité titrable ont été déterminées en utilisant les méthodes analytiques de l'Association of Official Analytical Chemists (AOAC). Les analyses microbiologiques, y compris la numération sur plaque standard (SPC) pour la flore mésophile aérobie totale (FMAT), les coliformes totaux (CT), les coliformes fécaux (CF), les levures, les clostridies, Staphylococcus aureus, les streptocoques fécaux et les numérations de salmonelles, ont été effectuées à l'aide de méthodes microbiologiques standard. L'identification des isolats de levure a été réalisée avec le kit d'identification biochimique API 20E du commerce. Résultats: Les charges microbiennes moyennes pour les échantillons d'olives traditionnelles étaient de $3,2 \times 10^{6}$ $\mathrm{UFC} / \mathrm{ml}$ pour le SPC, $1,7 \times 10^{4} \mathrm{UFC} / \mathrm{ml}$ pour le TC, $8,7 \times 10^{3} \mathrm{UFC} / \mathrm{ml}$ pour le FC et $2,5 \times 10^{6} \mathrm{UFC} / \mathrm{ml}$ pour la levure, qui étaient plus élevées par rapport aux charges microbiennes moyennes des olives industrielles avec des valeurs respectives de $5,9 \times 10^{5} \mathrm{UFC} / \mathrm{ml}, 5 \times 10^{1} \mathrm{UFC} / \mathrm{ml}, 0 \mathrm{UFC} / \mathrm{ml}$ et $0 \mathrm{UFC} / \mathrm{ml}$. Cent pour cent (56 sur 56) des olives traditionnelles (dénoyautées vertes et noires) des marchés de Témara-Rabat étaient contaminées par des coliformes tandis que $50 \%$ des olives vertes et $65 \%$ des olives noires de Salé-Rabat étaient contaminées par des coliformes. Cinq pour cent (5\%) de chacune des olives vertes et noires traditionnelles des marchés de Salé-Rabat étaient contaminées par des clostridia (bactéries sporulantes). Aucune FC ni aucune autre bactérie et levure n'étaient présentes dans les olives industrielles, et aucune des olives n'était contaminée par $S$. aureus, des streptocoques fécaux et des salmonelles. Sur un total de 8 souches de levure isolées des olives traditionnelles, 4 (50\%) étaient Candida guilliermondii, 2 (25\%) Candida lusitaniae et 2 (25\%) Candida famata.

Conclusion: La contamination des produits à base d'huile d'olive peut être due à différentes sources telles que l'eau, les matériaux de traitement, les conditions de stockage, le nettoyage, la main-d'œuvre et autres. Il est nécessaire d'accroître la sensibilisation et le contrôle de ceux-ci dans les points de vente de ces olives traditionnelles.

Mots-clés: hygiène; propriétés physico-chimiques; microbiologie; olives traditionnelles; qualité

\section{Introduction:}

Olive tree is a specific tree of the Mediterranean basin whose likely origin is Egypt, India, Syria or Ethiopia. Its cultivation in North Africa existed before the arrival of the Romans and the production of its oil was recognized about 7,000 years ago (1). In Morocco, the national production of table olives is about 2 million tons in year (2) for an area of 957,000 hectare, and the most widely available variety is the Moroccan picholine (Zitoune beldi). The regions in Morocco with highest production of olives are Marrakech, Safi, Beni Mellal, Khénifra, Tangier-Tétouan and Fés-Méknés. The three methods of olive preparations mostly practiced in Morocco are; the Spanish method for green olives, the Californian method for oxidized black olives and the Greek method for black olives, but the method most often used by industrialists is the Spanish preparation method which is an alkaline desamerization treatment of olives.

The presence of staphylococci, faecal streptococci, total coliforms, yeasts and molds contaminating table olives have been reported by many researchers in Morocco, especially in the regions of Rabat and Marrakech $(3,4)$. In addition, the presence of penicillium spores in olive samples (especially black olives) was reported by Maouni et al., (5) and Lamrani et al., (6) in the region of Fez Marrakech. Outside of Morocco, Caggia et al., (7) has isolated and identified Listeria monocytogenes in olive samples of traders in Italy, and fecal coliforms, streptococci and reductive sulfite clostridia were isolated from samples of commercial olives in Portugal (8). The objective of this study is to assess hygiene quality and identify the most predominant yeast species in traditional and industrial tables olives sold in the markets of two cities in Morocco.

\section{Materials and method:}

\section{Sampling:}

A total of 108 pitted black and green olive samples (96 traditional and 12 industrial) from markets in Temara-Rabat and SaléRabat in Morocco were collected for evaluation of the hygienic quality of these products for direct consumption. For each of the traditional black and green olive brands, 4 samples were collected from 7 points of sales from markets in both Temara-Rabat and Salé-Rabat. For the industrial olives, 6 samples were collected for each black and green olives ( 3 per brand). Samples were delivered to the laboratory directly in a cooler. The maximum time between sampling and sample analysis was one hour. All samples were analysed by and results obtained compared with national and international standards.

\section{Physico-chemical analysis of olive samples}

The $\mathrm{pH}$ and oxido-reduction potential (ORP) of samples were measured from a $20 \%$ dry matter solution using a multi-parameter measurement $\mathrm{pH}$ after the device has been calibrated using AOAC method 981.12 (9). The liquid solution of the product was prepared and analyzed by titrimetry at $\mathrm{pH} 8.1$ with $0.1 \mathrm{~N}$ sodium hydroxide solution $(\mathrm{NaOH})$ using $A O A C$ methods 920.149 (c), 942.15A and 942.15B (9). Total acidity of olives was expressed by convention in grams of citric acid. 


\section{Standard plate count (SPC) for total aerobic mesophilic flora}

The standard plate count (SPC) for total aerobic mesophilic flora (TAMF) was done after appropriate sample dilutions in peptone water buffered broth and subsequent seeding on the plate count agar (PCA) growth medium and incubation at $30^{\circ} \mathrm{C}$ for 72 hours (10).

\section{Total and fecal coliform counts}

Total coliform (TC) and faecal coliform (FC) counts were done by culturing appropriate sample dilution of olives on MacConkey agar plate and incubating at $30^{\circ} \mathrm{C}$ for $\mathrm{TC}$ and $44^{\circ} \mathrm{C}$ for FC. After 24 hours of incubation, red colonies were counted (11).

\section{Staphylococcus aureus (SA) count:}

Staphylococcus aureus count was performed by inoculating Baird Parker culture medium with appropriate olive sample dilution and incubating aerobically at $37^{\circ} \mathrm{C}$ for 24 hours (12).

\section{Faecal streptococci (FS) count}

Faecal streptococci count was done on Rothe broth and after incubation at $37^{\circ} \mathrm{C}$ for 24 hours, positive tubes were seeded on Litsky broth and incubated at $37^{\circ} \mathrm{C}$ for 24 hours (13).

\section{Salmonella count}

Pre-enrichment was done by adding $25 \mathrm{ml}$ of olive sample to $225 \mathrm{ml}$ of sterile peptone water dabbed in a $250 \mathrm{ml}$ Erlenmeyer flask, which was incubated at $37^{\circ} \mathrm{C}$ for $12 \mathrm{hrs}$. Enrichment was done using two broths; Muller Kaufman and tetrathionate (MKTn) broth (Merck, Germany). MKTn tubes showing positive result were sub-cultured onto XLDA agar for Salmonella, where positive colonies appeared green (14). Identification was done by the procedure described by Poelma (15).

\section{Reducing sulfito count for anaerobic spore forming bacteria (SFB)}

The count for anaerobic spore forming bacteria (clostridia) was performed on Sodium Sulphite - Polymyxin - Cysteine Sulphite (SPS) medium. The sample solution was first heattreated at $80^{\circ} \mathrm{C}$ for 10 minutes, after which SPS medium was seeded and incubated at $30^{\circ} \mathrm{C}$ for $24-48$ hours. Only black colonies were counted (16).

\section{Lactic acid bacteria count}

Lactic acid bacteria count was carried out using Man Rogosa and Sharpe (MRS) medium. Incubation was done at $30^{\circ} \mathrm{C}$ for mesophilic species and $45^{\circ} \mathrm{C}$ for thermophilic species for 48 hours. Round shape or lenticular colonies were counted (17).

\section{Yeast enumeration and identification}

The method used consists of seeding Potato Dextrose Agar (PDA) that has been highly acidified $(\mathrm{pH} 3-3.5)$ by lactic acid. The count was carried out after 3 days of incubation at $37^{\circ} \mathrm{C}$ for yeasts and after 4 days of incubation at $30^{\circ} \mathrm{C}$ for moulds (18). The identification of yeast isolates was carried out using the commercial biochemical API 20E kit (19).

\section{Results:}

The physico-chemical analysis of the traditional green and black olive samples from the different outlets showed average $\mathrm{pH}$, acidity and oxido-reduction potential (OPR) values for green olives of $4.4 ; 11.8$ and 135.5 respectively, while for the black olives, the respective values were $6.3,8.1$ and 8.0 . For the industrial olives, the values of $\mathrm{pH}$, acidity and OPR of the black olives are respectively $4.5,5.5$ and 129.5 while the respective values for green olives are 5.9, 8.5 and 92.5 (Table $1)$.

Microbiological analyses of the black olive samples showed the average microbial loads for traditional olive samples as; $3.2 \times 10^{6}$ for SPC, $1.3 \times 10^{4}$ for TC, $8.7 \times 10^{3}$ for FC, and $2.5 \times 10^{6}$ for yeast, which were higher compared to the average microbial loads of industrial olives with values of $5.9 \times 10^{5}, 5 \times 10^{1}$, $0 \mathrm{CFU} / \mathrm{ml}$ and $0 \mathrm{CFU} / \mathrm{ml}$ respectively. One hundred percent ( 56 of 56 ) of the traditional olives (pitted green and black) from TemaraRabat markets were contaminated with coliforms (TC and FC) while $50 \%$ of green and $65 \%$ of black olives in Salé-Rabat markets were contaminated with coliforms.

Five percent $(5 \%)$ each of the traditional green and black olives in Salé-Rabat were contaminated with clostridia (spore forming bacteria). No FC or other bacteria and yeasts were present in the industrial olives, and none of the olives was contaminated with S. aureus, faecal streptococci and salmonella. Of the total of 8 yeast strains isolated from the traditional olives, 4 (50\%) were Candida guilliermondii, 2 (25\%) were Candida lusitaniae and $2(25 \%)$ were Candida famata (Fig 1). 
Table 1: Physico-chemical composition of traditional and industrial pitted olives in Morocco

\begin{tabular}{|c|c|c|c|c|c|c|c|c|c|c|c|}
\hline \multirow[t]{2}{*}{ Type of olives } & \multirow[t]{2}{*}{ Point of sale (PS) } & \multirow[t]{2}{*}{$\begin{array}{l}\text { Number of } \\
\text { sample }\end{array}$} & \multicolumn{3}{|c|}{$\mathrm{pH}$} & \multicolumn{3}{|c|}{ Acidity $^{\circ} \mathrm{D}$} & \multicolumn{3}{|c|}{$\begin{array}{c}\text { Oxido-reduction potential } \\
\text { ORP (mV) }\end{array}$} \\
\hline & & & Min & Max & Average & Min & Max & Average & Min & Max & Average \\
\hline \multirow[t]{4}{*}{ Traditional pitted green } & $\begin{array}{c}\text { PS1 to PS7 } \\
\text { (Rabat-Temara) }\end{array}$ & 28 & 3.34 & 4.62 & 4.17 & 7.7 & 19.7 & 11.8 & 111.6 & 200.8 & 144.6 \\
\hline & $\begin{array}{l}\text { PS8 to PS12 } \\
\text { (Rabat-Salé) }\end{array}$ & 20 & - & - & 4.60 & - & - & - & - & - & 123.5 \\
\hline & Total & 48 & & & 4.35 & & & 11.8 & & & 135.5 \\
\hline & $\begin{array}{c}\text { PS1 to PS7 } \\
\text { (Rabat-Temara) }\end{array}$ & 28 & 6.08 & 7.69 & 6.90 & 7.50 & 9.00 & 8.07 & -35.10 & 27.60 & -4.11 \\
\hline Traditional pitted black & $\begin{array}{c}\text { PS8 to PS12 } \\
\text { (Rabat-Salé) } \\
\text { Total }\end{array}$ & $\begin{array}{l}20 \\
48\end{array}$ & - & - & $\begin{array}{c}5.54 \\
6.3\end{array}$ & - & - & $\begin{array}{c}- \\
8.07\end{array}$ & - & - & $\begin{array}{c}24.8 \\
8\end{array}$ \\
\hline Industrial pitted green & Brand 1 and 2 & 6 & 5.43 & 6.39 & 5.91 & 3.00 & 14 & 8.5 & 17.70 & 74.83 & 92.53 \\
\hline Industrial pitted black & Brand 1 and 2 & 6 & 4.51 & 4.57 & 4.54 & 4.66 & 6.33 & 5.49 & 127.26 & 131.86 & 129.56 \\
\hline
\end{tabular}

Table 2: Microbial contamination of traditional and industrial olives in Morocco

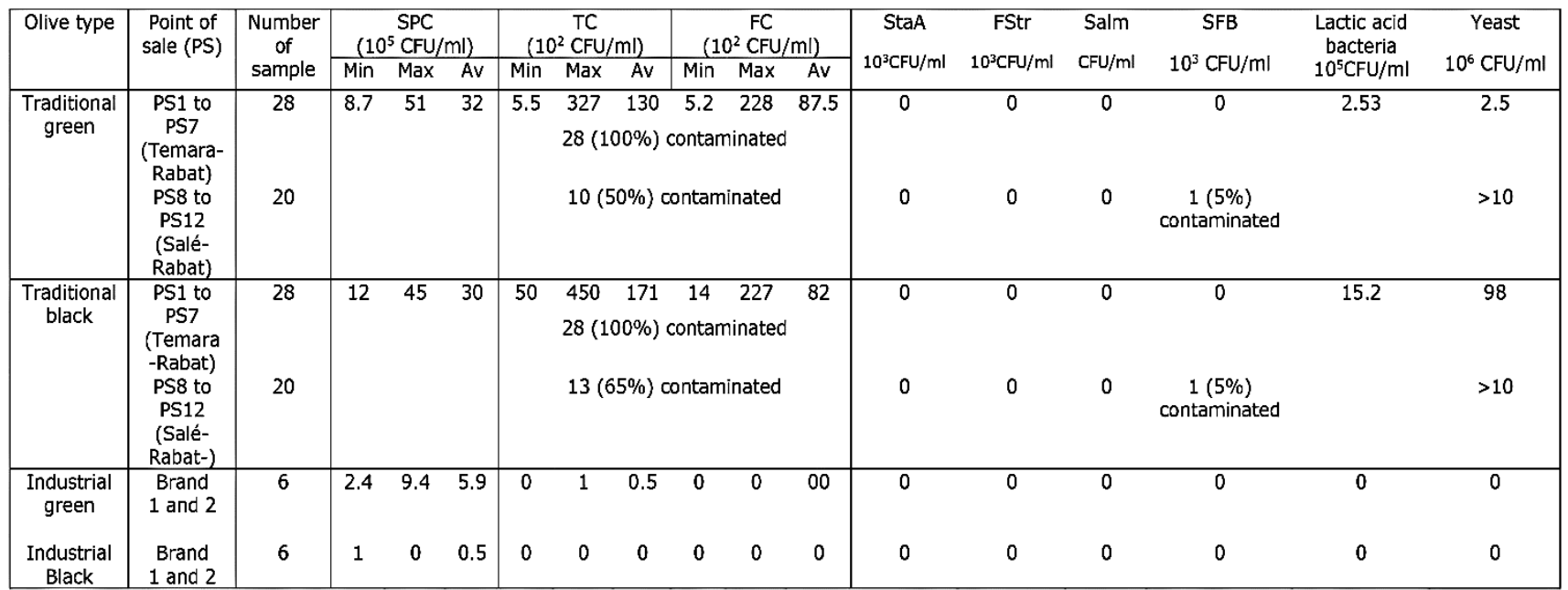

TC: coliforms; FC: fecal coliforms; SPC: Standard Plate Count; FStr: fecal streptococci; SFB: spore forming bacteria; StaA: Staphylococcus aureus; Salm: salmonella; Min: minimum; Max: maximum; Av: average; CFU: colony forming unit

\section{Yeast identification}

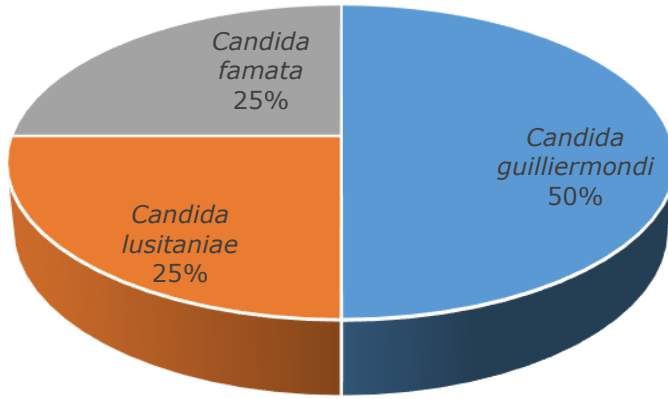

Fig 1: Candida species isolated from table olives in Morocco

\section{Discussion:}

The oxido-reduction potential (ORP) of traditional green olives in this study was very high compared to that of the black olives of the same type, but almost similar to that of industrial green olives, therefore the $\mathrm{pH}$ of green olive is acidic compared to black olive which is close to neutrality. The $\mathrm{pH}$ is correlated with the amount of free fatty and organic fatty acids produced by microorganisms (20), and the recommended maximum $\mathrm{pH}$ value should be less than 4.3 (21). However, the values obtained in our study are higher than those reported previously (22). The acidity values reported by the IOC ( $\mathrm{pH} 0.3-0.5)$ and those by Kailis and Harris (23), and Ünal and Cevdet (24) were lower than our values, which may relate to the treatment conditions and lactic acid activity of the olives.

Traditional green and black olive samples from Témara-Rabat markets were more contaminated with coliforms (100\%) when compared to those from Salé-Rabat markets with $50 \%$ and $65 \%$ contamination for green and black olives respectively, and $5 \%$ of both olive types were contaminated by clostridia. Coliforms and clostridia contaminations have been reported in traditional olives in Portugal (8) and in Marrakech region of Morocco (3). In another study, Maouni et al., (5) reported that household-prepared table olives had more microbial loads than the commercial olives. The high aerobic flora load in the traditional 
green olive samples can be explained by the low salt content (less than 6\%) which increase acidity, and by prolonged storage at the orchard level, which increase exposure to microbial contaminants. Also, there may be proliferation of microorganisms at the traditional olive preparation and extended openair storage at room temperature. However, there was no such contamination with the industrial olives, probably the result of heat treatment and good hygiene during preparation, which therefore make them safe for consumption.

For the yeast contents, the values reported in this study exceed the recommended standards, which can lead to the deterioration of the olives with release of $\mathrm{CO}_{2}$, resulting in bad odors (25). Candida guilliermondii was the most commonly identified yeast specie in the contaminated olive samples. This species has been reported as essential for fermentation of traditional olives in Italy $(26)$ and Morocco $(27,28)$. Candida famata and $C$. Iusitaniae were the other species identified in our study that have been reported as normal flora during fermentation process of olives in Turkey (29).

\section{Conclusion:}

Microbiological analyses of the traditional olive samples show the presence of faecal flora especially clostridia in the samples, which is an indicator of poor hygienic conditions in the preparation of these olives. Our findings should inform preparers of the risks associated with poor hygiene in preparation of the olives, and encourage measures such as pasteurization, environmental and instrument cleanliness, availability of water sanitation and hygiene (WASH) facilities, proper packaging of finished products, and cooling, that can help reduce microbial contaminations during preparation.

\section{References:}

1. Tsagaraki, E., Lazarides, H., and Petrotos, K. Olive Mill Wastewater Treatment. Utilization of By-Products and
Treatment of Waste in the Food Industry. 2006 Ministry of Agriculture, Morocco, 2018

2. Moumene, H., Hasib, A., Amir, S., and Jaouad, A. Hygienic quality of collected table olives outlets in the region of Marrakech-Tensift El Hawz. Les technologies de laboratoire. 2013; 8: 32

Asehraou, $A$, Asehraou, A., Faid, M and Jana, $M$. properties and the microflora of Moroccan black table olives. Grasas y Aceites, 1992; 43: 3

5. Maouni, A., Khaddor, M., Lamarti, A., and Badoc, A. Recherche des penicilliums toxinogènes contaminant

les olives de table. Bull Soc Pharm Bordeaux. 2002; 141: 53-60.

amrani, K., Lakhtar, $\mathrm{H}$., Cheheb, M., Ismaili-Alaoui, M., Augur, C., Macarie, H., Perraud-Gaime, I., and Roussos, $S$. Natural microflora on olives and risk assessment. In: Koutinas, A. Pandey, A. Larroche C (eds.). Current Topics on Bioprocesses in Food Industry. Volume II, Asiatech Publishers Inc., 2008: 223-235

7. Caggia, C., Randazzo, C. L., Salvo, M., Romeo, F., and Guidici, P. Occurrence of Listeria monocytogenes in green table olives. Journal of Food Protection. 2004; 67: 2189 - 2194

8. Pereira, A. P., Pereira, J. A., Bento, A. M., and Estevinho, Pereira, A. P., Pereira, J. A., Bento, A. M., and Estevinho, L. Microbiological characterization of table olives comercialized in Portugal in respect to safety aspect. Food and Chemical Toxicology. 2008; 46: 2895-2902.

9. AOAC. Official methods of analysis. Association of Official Analytical Chemists, 15th Edition, Washington, D.C., USA, 1990

10. NM ISO 483. Food Microbiology - Horizontal Method for Counting Microorganisms - Colony Counting Technique at $30^{\circ} \mathrm{C}$. Rev, IC08.4.102. 2008: 13

11. Standards NM 08.0.124. Food Microbiology - Counting thermotolerant Coliforms by colony counting at $44^{\circ} \mathrm{C}-$ thermotolerant Coliforms

12. NM ISO 6888-1. Food Microbiology - Horizontal method for counting positive coagulase staphylococci (Staphylococcus aureus and other species) - Part I: Technique using Baird-Parker's gélodosis medium; Rev, IC08.0.150. 2008: 21

13. DIN-10106. Microbiological analysis of meat and meat products; determination of Enterococcus faecalis and products; determination of Enterococcus faecalis and

14. ISO 6579-1. Microbiology of the food chain - Horizontal method for the detection, enumeration and serotyping of Salmonella - Part 1: Detection of Salmonella spp. 2017.

15. Poelma, P. L., Andrews, W. H., and Silliker, J. H. Salmonella In: Speck, M. L. (ed). Compendium of Methods for the Microbiological Examination of Foods, American Public Health Association, 2ed.Washington DC: 1984: 286-320 NM 08.0.125. Food Microbiology - Ana: 1984: 286-320 NM 08.0.125. Food Microbiology - Anaerobiosis count of sulphate-reducing bacteria by colony count-Routine method. 2006; 7

17. NF ISO 15214 (V 08-030). Food microbiology. Horizontal method for counting mesophilic lactic bacteria. Colony counting technique at $30^{\circ} \mathrm{C}$. September 1998.

18. NM 08.0.123. Food Microbiology-Yeast and Mold Counting by Colony Counting at 250C - Routine Method, 2005; 6 Bio Mérieux, Marcy l'Etoile, France

10. Sakouhi, F Harrabi, S Absalon, $C$ Sbei, K Boukhchina S., and Kallel, H. a-tocopherol and fatty acids contents of some Tunisian table olives (Olea europea $\mathrm{L}$ ): Changes in their composition during ripening and processing. Food Chemistry. 2008; 108: 833-839.

21. IOC; International Olive Council, 2007

22. Efstathios, P., and Constantinos, Z. K. Effect of different brining treatments on the fermentation of $\mathrm{CV}$. Conservolea green olives processed by the Spanish-method. Food Microbiology. 2006; 23 (2): 199-20

23. Kailis, S. G and Harris, D. Producing table olives. Kailis, S. G., and Harris, D. Producing table olives. Landlinks Press. Australia, 2007: 76 - 82 Ünal, K., and Cevdet, N. The effect of table olive preparing methods and storage on the composition and nutritive value of olives. Grasas y Aceites. 2003; 54 (1): Garrido Fernández A., Adams R. M., and Fernández Diez, M. J. Table olives: Production and processing. Chapman and Hall, London, 1997

Bevilacqua, A., Rosaria Corbo, M., and Sinigaglia, M. Selection of Yeasts as Starter Cultures for Table Olives: A Step-by-Step Procedure. Front Microbiol. 2012; 3: 194 A Step-by-Step Procedure. Front Microbiol. 2012; 3: 194 Candida guilliermondii and Lactobacillus amylovorus as a starter culture for fermented olives: isolation and application . Am J Innov Res Appl Sci. 2016;2(1):10-15 Sobh, M., Chaouch, A., Echchelh, A., Oudda, H., and Ouhssine, M. Optimization of the synthesis parameters extracellular for strain isolated Candida guilliermondii brine olives. BioTechnology: An Indian Journal (BTAIJ). 2013; 7 (1): 1-5

29. Mujdeci, G., Arévalo-Villena, M., Ozbas, Z. Y., and Briones Pérez, A. Yeast Identification During Fermentation of Turkish Gemlik Olives. J Food Sci. 2018; 83 (5): 13211325 